\title{
Insulin secretion in islets from mice with a double knockout for the dense core vesicle proteins islet antigen-2 (IA-2) and IA-2 $\beta$
}

\author{
Jean-Claude Henquin, Myriam Nenquin, Andras Szollosi, Atsutaka Kubosaki ${ }^{1}$ and Abner Louis Notkins ${ }^{\mathbf{1}}$ \\ Unit of Endocrinology and Metabolism, Faculty of Medicine, University of Louvain, UCL 55.30, Avenue Hippocrate 55, B-1200 Brussels, Belgium \\ ${ }^{1}$ Experimental Medicine Section, Oral Infection and Immunity Branch, National Institute of Dental and Craniofacial Research, National Institutes of Health, \\ Bethesda 20891, MD, USA \\ (Correspondence should be addressed to J-C Henquin; Email: jean-claude.henquin@uclouvain.be)
}

\begin{abstract}
Islet antigen-2 (IA-2 or ICA 512) and IA-2 $\beta$ (or phogrin) are major autoantigens in type 1 diabetes. They are located in dense core secretory vesicles including insulin granules, but their role in $\beta$-cell function is unclear. Targeted disruption of either IA-2 or IA-2 $\beta$, or both, impaired glucose tolerance, an effect attributed to diminution of insulin secretion. In this study, we therefore characterized the dynamic changes in cytosolic $\mathrm{Ca}^{2+}\left(\left[\mathrm{Ca}^{2+}\right]_{\mathrm{c}}\right)$ and insulin secretion in islets from IA-2/IA-2 $\beta$ double knockout $(\mathrm{KO})$ mice. High glucose $(15 \mathrm{mM})$ induced biphasic insulin secretion in IA-2/IA-2 $\beta$ KO islets, with a similar first phase and smaller second phase compared with controls. Since the insulin content of IA-2/IA-2 $\beta$ KO islets was $~ 45 \%$ less than that of controls, fractional insulin secretion (relative to content) was thus increased during first phase and unaffected
\end{abstract}

during second phase. This peculiar response occurred in spite of a slightly smaller rise in $\left[\mathrm{Ca}^{2+}\right]_{c}$, could not be attributed to an alteration of glucose metabolism (NADPH fluorescence) and also was observed with tolbutamide. The dual control of insulin secretion via the $\mathrm{K}_{\mathrm{ATP}}$ channel-dependent triggering pathway and $\mathrm{K}_{\mathrm{ATP}}$ channel-independent amplifying pathway was unaltered in IA-2/IA- $2 \beta \mathrm{KO}$ islets, and so were the potentiations by acetylcholine or cAMP (forskolin). Intriguingly, amino acids, in particular the cationic arginine and lysine, induced larger fractional insulin secretion in IA-2/IA-2 $\beta$ KO than control islets. In conclusion, IA-2 and IA- $2 \beta$ are dispensable for exocytosis of insulin granules, but are probably more important for cargo loading and/or stability of dense core vesicles.

Journal of Endocrinology (2008) 196, 573-581

\section{Introduction}

Islet antigen-2 (IA-2, also known as islet cell antigen 512) and IA-2 $\beta$, (also known as phogrin) are major autoantigens in type 1 diabetes. Autoantibodies against both proteins appear before the development of clinical diabetes, and their presence is widely used to identify high-risk subjects (Notkins \& Lernmark 2001).

IA- 2 and IA-2 $\beta$ are members of the transmembrane protein tyrosine-phosphatase family (Lan et al. 1994, Rabin et al. 1994, Cui et al. 1996, Kawasaki et al. 1996, Lu et al. 1996, Solimena et al. 1996), but are enzymatically inactive. They are predominantly located in the membrane of dense core secretory vesicles (DCV) of various neuroendocrine tissues, including pancreatic islets (Solimena et al. 1996, Wasmeier \& Hutton 1996). Their physiological role in $\beta$-cell function has remained unclear even though recent data suggest a contribution to the regulation of insulin secretion and biosynthesis or to the stability of DCV.

Glucose and cAMP have been found to increase IA-2 mRNA and protein in rat islets (particularly during the postnatal period), whereas IA- $2 \beta$ expression was unaffected (Löbner et al. 2002). In the INS1 cell line, cAMP rapidly increased IA-2 gene expression, whereas an effect of glucose was detectable only after prolonged stimulation (Seissler et al. 2000).
In insulin-secreting MIN-6 cells, IA-2 $\beta$ is phosphorylated upon stimulation by glucose, $\mathrm{KCl}$, or forskolin (that raises cAMP). The effect of glucose and $\mathrm{KCl}$ is $\mathrm{Ca}^{2+}$ dependent and attributed to $\mathrm{Ca} /$ calmodulin-dependent kinase II, whereas the effect of forskolin, presumably mediated by protein kinase $\mathrm{A}$, is $\mathrm{Ca}^{2+}$ independent (Wasmeier \& Hutton 1999, 2001). These observations prompted the proposal that IA-2 $\beta$ plays a role in the priming of insulin granules for exocytosis. In contrast, overexpression of IA-2 $\beta$ (but not IA-2) was reported to inhibit glucose-induced insulin secretion in MIN-6 cells, which prompted the suggestion that IA-2 $\beta$ might exert an inhibitory action on secretion (Doi et al. 2006).

An appealing hypothesis, which however awaits independent testing, proposes that, upon exocytosis of insulin granules, the cytoplasmic tail of IA- 2 is cleaved by a $\mathrm{Ca}^{2+}$-dependent calpain and translocates to the nucleus where, via STAT 5, it promotes transcription of the insulin gene (Trajkovski et al. 2004, Mziaut et al. 2006). In contrast, IA-2 $\beta$ appears to be recycled in new secretory vesicles (Vo et al. 2004).

Targeted deletion of the IA-2 gene resulted in mild glucose intolerance of the mice, which was attributed to depressed insulin secretion (Saeki et al. 2002). This interpretation was supported by in vitro studies showing a $45 \%$ decrease in glucose-induced insulin 
secretion by IA-2 knockout (KO) islets versus controls (Saeki et al. 2002). Moreover, knockdown of IA-2 in MIN-6 cells decreased the number of DCV, the insulin content, and insulin secretion, whereas the overexpression of IA-2 had the opposite effects (Harashima et al. 2005). Mice with a selective knockout of IA- $2 \beta$ resembled IA-2 KO mice, with, however, a slightly lesser $(\sim 35 \%)$ inhibition of glucose-induced insulin secretion in incubated islets (Kubosaki et al. 2004). Mice with a double knockout for IA-2 and IA-2 $\beta$ were then produced (Kubosaki et al. 2005). Again, glucose intolerance was observed, with a marked impairment of the rapid rise in plasma insulin after ip glucose administration. In contrast, the rapid increase in plasma insulin induced by arginine persisted (Kubosaki et al. 2005).

All these studies suggest a role of IA-2 and IA- $2 \beta$ in the regulation of secretory granule number in $\beta$-cells and possibly of insulin secretion. To address the latter question more directly, we characterized the dynamic changes in cytosolic $\mathrm{Ca}^{2+}$ concentration $\left(\left[\mathrm{Ca}^{2+}\right]_{c}\right)$ and insulin secretion in islets isolated from IA-2 and IA- $2 \beta$ double knockout mice.

\section{Materials and Methods}

The study was approved by, and the experiments were conducted in accordance with, the guidelines of the Animal Research Committees of the respective institutions.

\section{Animals}

The generation and characteristics of IA-2/IA-2 $\beta$ double knockout mice have been described previously (Kubosaki et al. 2005). Adult animals and their controls were sent from Bethesda to Brussels, where they were used at an age of 13-18 months. All experiments were done with female mice. There was no difference between body weight $(32.7 \pm 1.5$ vs $35.5 \pm 1.7 \mathrm{~g}$, $n=12)$ and morning blood glucose $(7 \cdot 4 \pm 0 \cdot 4$ vs $7 \cdot 3 \pm 0 \cdot 5 \mathrm{mM})$, but plasma insulin levels were lower $(P<0 \cdot 001)$ in control than IA- $2 / \mathrm{IA}-2 \beta \mathrm{KO}$ mice $(2 \cdot 17 \pm 0 \cdot 33$ vs $4 \cdot 08 \pm 0 \cdot 32 \mathrm{ng} / \mathrm{ml})$.

\section{Solutions and reagents}

The control medium was a bicarbonate-buffered solution containing $(\mathrm{mM}): \mathrm{NaCl}, 120 ; \mathrm{KCl}, 4 \cdot 8 ; \mathrm{CaCl}_{2}, 2 \cdot 5 ; \mathrm{MgCl}_{2}$, 1.2; and $\mathrm{NaHCO}_{3}$, 24. It was gassed with $\mathrm{O}_{2} / \mathrm{CO}_{2}(94 \%: 6 \%)$ to maintain a $\mathrm{pH} 7 \cdot 4$, and it contained $10 \mathrm{mM}$ glucose and $1 \mathrm{mg} / \mathrm{ml} \mathrm{BSA}$. A similar solution was used as test medium after adjustment of the glucose concentration and addition of the studied substances. When the concentration of $\mathrm{KCl}$ was increased, then that of $\mathrm{NaCl}$ was decreased accordingly.

Diazoxide was a gift of Schering-Plough, Brussels. Other reagents were from Sigma or from Merck AG.

\section{Preparations}

Islets from IA-2/IA-2 $\beta \mathrm{KO}$ or control mice were aseptically isolated by collagenase digestion of the pancreas followed by hand selection (Jonas et al. 1998). The islets were then cultured for about $18 \mathrm{~h}$ in RPMI 1640 medium (Invitrogen) containing $10 \mathrm{mM}$ glucose, $10 \%$ heat-inactivated fetal calf serum, $100 \mathrm{IU} / \mathrm{ml}$ penicillin, and $100 \mu \mathrm{g} / \mathrm{ml}$ streptomycin.

\section{Measurements of insulin secretion and islet insulin content}

After overnight culture, batches of 20 islets were transferred into the chambers of a perifusion system (Henquin et al. 2006) and perifused at $37^{\circ} \mathrm{C}$ with test solutions, the composition of which is described at the top and in the legend of each figure. The effluent fractions were collected at 1 - $\mathrm{min}$ (first $10 \mathrm{~min}$ of glucose stimulation) or 2-min intervals, and saved for insulin assay, using rat insulin as a standard and ethanol to precipitate bound insulin (Heding 1972). At the end of the experiments, the islets were recovered from the chambers and their insulin content was determined after extraction in acid-ethanol. Fractional insulin secretion rate was then calculated as the percentage of islet insulin content that was secreted per minute.

\section{Measurements of islet $\left[\mathrm{Ca}^{2+}\right]_{c}$ and $\mathrm{NAD}(\mathrm{P}) \mathrm{H}$}

Overnight cultured islets were loaded with the $\mathrm{Ca}^{2+}$-indicator fura-PE3 $(2 \mu \mathrm{M}, 2 \mathrm{~h})$ in control medium containing $10 \mathrm{mM}$ glucose. Loaded islets were then transferred into the perifusion chamber of a spectrofluorimetric system, equipped with a camera, and with which $\left[\mathrm{Ca}^{2+}\right]_{\mathrm{c}}$ was measured as described previously (Gilon \& Henquin 1992). Because of technical constraints, the $\left[\mathrm{Ca}^{2+}\right]_{c}$ experiments are shorter than insulin secretion experiments. The islets to be used for $\mathrm{NAD}(\mathrm{P}) \mathrm{H}$ measurements were preincubated without dye before transfer into the chamber. Recordings of the fluorescence were done as reported (Gilon \& Henquin 1992). In both $\left[\mathrm{Ca}^{2+}\right]_{\mathrm{c}}$ and $\mathrm{NAD}(\mathrm{P}) \mathrm{H}$ measurements, control and IA-2/IA- $2 \beta$ KO islets were placed side by side in the chamber and the recordings were performed simultaneously.

\section{Presentation of results}

All experiments have been performed with islets from four to five different preparations. Except for representative recordings of $\left[\mathrm{Ca}^{2+}\right]_{\mathrm{c}}$ in individual islets, results are presented as means \pm s.E.M. The statistical significance of differences between IA-2/IA- $2 \beta \mathrm{KO}$ and control islets was assessed by unpaired Student's $t$-test.

\section{Results}

\section{Effects of glucose}

The effects of glucose on $\beta$-cell metabolism were estimated by measuring the $\mathrm{NAD}(\mathrm{P}) \mathrm{H}$ fluorescence of the islets (Panten et al. 1973). Raising the concentration of glucose from 1 to $15 \mathrm{mM}$ similarly increased the signal in control and IA-2/IA- $2 \beta \mathrm{KO}$ islets (Fig. 1A, inset). 

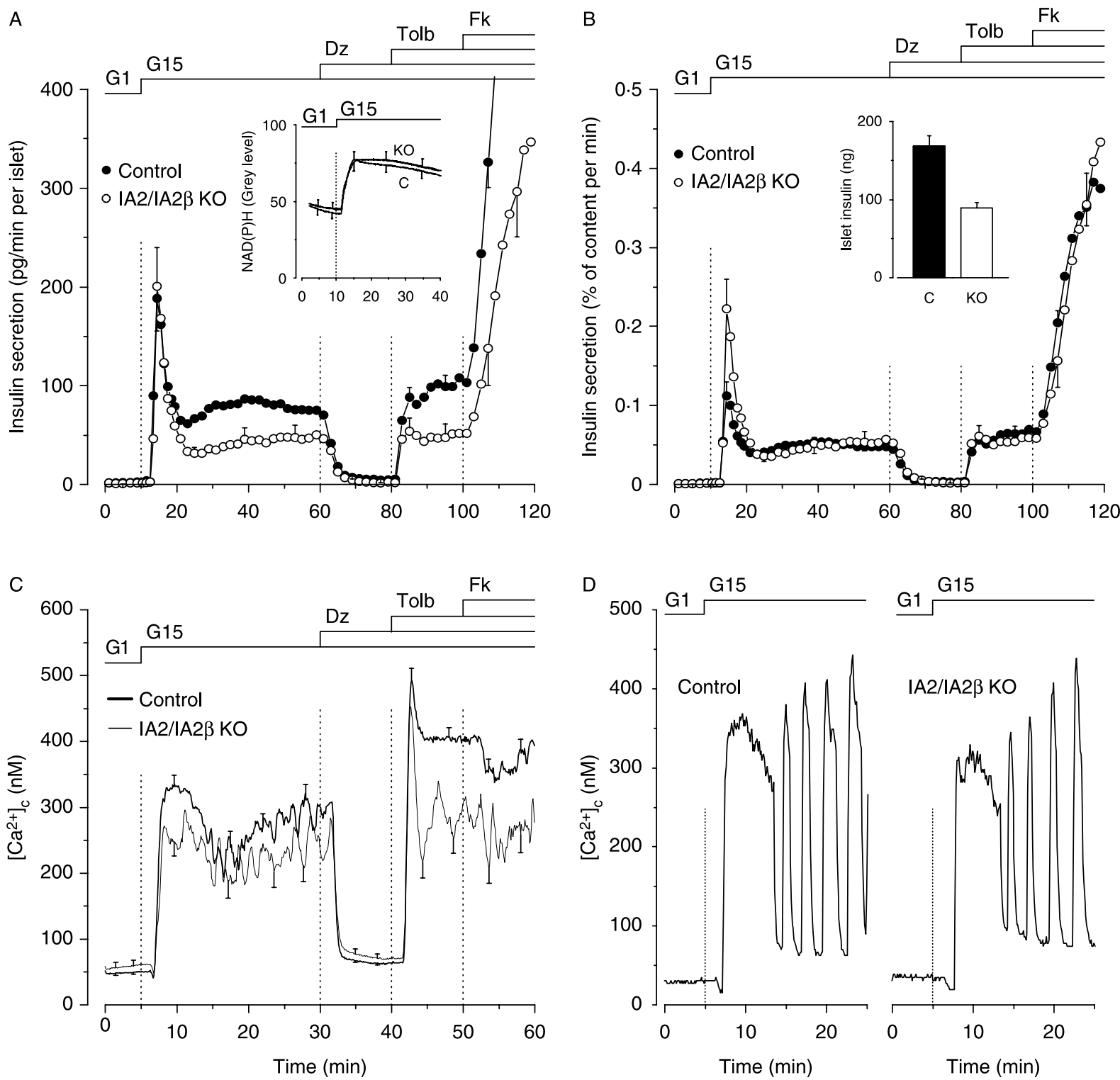

Figure 1 Glucose-induced insulin secretory $(\mathrm{A}$ and $\mathrm{B})$ and $\left[\mathrm{Ca}^{2+}\right]_{\mathrm{C}}(\mathrm{C}$ and $\mathrm{D})$ changes in control and IA-2/IA-2 $\beta \mathrm{KO}$ islets. The concentration of glucose was increased from 1 to $15 \mathrm{mM}(\mathrm{G} 1, \mathrm{G} 15)$, and diazoxide (Dz, $100 \mu \mathrm{M})$, tolbutamide (Tolb, $100 \mu \mathrm{M})$, and forskolin $(\mathrm{Fk}, 1 \mu \mathrm{M})$ were then added sequentially as shown at the top of each panel. (A) Insulin secretion is expressed in absolute terms (as pg/islet). The inset shows the increase in $\mathrm{NAD}(\mathrm{P}) \mathrm{H}$ fluorescence produced by $15 \mathrm{mM}$ glucose in control and IA-2/IA-2 $\beta \mathrm{KO}$ islets. (B) Insulin secretion (same experiments as in A) is expressed as a percentage of the islet insulin content, which is shown in the inset. (C) Average changes in $\left[\mathrm{Ca}^{2+}\right]_{\mathrm{C}}$ in the two groups of islets. (D) Representative changes in $\left[\mathrm{Ca}^{2+}\right]_{\mathrm{C}}$ produced by $15 \mathrm{mM}$ glucose in one control and one IA-2/IA-2 $\beta \mathrm{KO}$ islet. Except in (D), values are means \pm s.E.M. for five experiments of insulin secretion and islet insulin content, 18 islets from three mice for $\operatorname{NADP}(\mathrm{H})$, and 27 islets from five mice for $\left[\mathrm{Ca}^{2+}\right]_{\mathrm{c}}$.

High glucose induced typical biphasic insulin secretion in control islets (Henquin et al. 2006; Fig. 1A). Opening ATPsensitive $\mathrm{K}\left(\mathrm{K}_{\text {ATP }}\right)$ channels with diazoxide abolished glucoseinduced secretion, and this inhibition was reversed by closing $\mathrm{K}_{\text {ATP }}$ channels with tolbutamide. Increasing islet cAMP levels with forskolin strongly potentiated insulin secretion. As also shown in Fig. 1A, the kinetics of insulin secretion changes observed in IA-2/IA-2 $\beta$ KO islets was similar to controls, but the secretory rate was smaller $(P<0 \cdot 05)$, except during the first-phase response to $15 \mathrm{mM}$ glucose.

The insulin content of IA-2/IA- $2 \beta \mathrm{KO}$ islets was, on average, $45 \%$ lower than that in controls $(88 \pm 4$ vs $162 \pm 5 \mathrm{ng}$ /islet, $n=30$ ) and the difference for this particular group is shown by the inset in Fig. 1B. To take into account this substantial difference in insulin stores, we expressed insulin secretion as a fractional secretory rate (Fig. 1B). Insulin secretion was virtually identical 
in the two groups of islets, except during the first phase, which was larger in IA-2/IA-2 $\beta$ KO than control islets $(P<0 \cdot 01)$. In all following figures, insulin secretion will be presented as a fractional secretory rate, but division by two of the values for IA- $2 / \mathrm{IA}-2 \beta \mathrm{KO}$ islets permits a reasonably correct comparison of the absolute rates of secretion in test and control groups.

In control islets, high glucose caused an initial small decrease in $\left[\mathrm{Ca}^{2+}\right]_{\mathrm{c}}$ followed by a first-phase increase and oscillations during steady-state stimulation (Fig. 1C and D; Gilon \& Henquin 1992). Diazoxide lowered $\left[\mathrm{Ca}^{2+}\right]_{c}$, tolbutamide reversed this inhibition, and forskolin caused a small inconstant decrease. This shows that the changes in secretion followed the changes in triggering $\left[\mathrm{Ca}^{2+}\right]_{\mathrm{c}}$, except when cAMP (forskolin) potentiated secretion, an effect attributed to mechanisms distal to the $\left[\mathrm{Ca}^{2+}\right]_{\mathrm{c}}$ rise (Tamagawa et al. 1985, Ammala et al. 1993). The changes in $\left[\mathrm{Ca}^{2+}\right]_{\mathrm{c}}$ measured in IA-2/IA-2 $\beta$ KO islets followed the same kinetics as in controls, but were of slightly smaller amplitude. The difference was significant $(P<0 \cdot 001)$ during the first phase of glucose stimulation but not quite $(P=0 \cdot 08)$ during the second phase. Qualitatively, the $\left[\mathrm{Ca}^{2+}\right]_{\mathrm{c}}$ response was normal, with well-defined oscillations (Fig. 1D). These oscillations are largely damped in the averaged traces shown in Fig. 1C.

\section{Insulin secretion through the amplifying pathway}

A high concentration of tolbutamide $(500 \mu \mathrm{M})$ was used to close all $\mathrm{K}_{\text {ATP }}$ channels in $\beta$-cells. This resulted in biphasic increases in $\left[\mathrm{Ca}^{2+}\right]_{c}$ and insulin secretion in control islets perifused with $1 \mathrm{mM}$ glucose (Fig. 2). When glucose was subsequently increased to $15 \mathrm{mM},\left[\mathrm{Ca}^{2+}\right]_{\mathrm{c}}$ initially decreased before returning to levels slightly above the prestimulatory values, while insulin secretion increased about fourfold (Fig. 2). Returning to $1 \mathrm{mM}$ glucose was followed by a decrease in secretion without a decrease in $\left[\mathrm{Ca}^{2+}\right]_{c}$. The stimulatory effect of glucose under these conditions corresponds to the $\mathrm{K}_{\text {ATP }}$ channel-independent amplifying pathway (Sato et al. 1999, Henquin et al. 2003). A similar time course characterized the insulin secretion and $\left[\mathrm{Ca}^{2+}\right]_{c}$ changes in IA-2/IA-2 $\beta \mathrm{KO}$ islets (Fig. 2). Except during the immediate response to tolbutamide, absolute insulin secretion rates were lower in IA-2/IA-2 $\beta \mathrm{KO}$ than control islets (not shown). When the difference in insulin content was taken into account, fractional insulin secretion rate was larger $(P<0 \cdot 01)$ in IA-2/IA-2 $\beta$ KO than control islets during the initial response to tolbutamide, and similar during steady-state stimulation (Fig. 2A), in spite of slightly smaller elevations of $\left[\mathrm{Ca}^{2+}\right]_{\mathrm{c}}$ during both initial peak $(P<0.02)$ and plateau $(P<0 \cdot 001)$ (Fig. 2B). Amplification of insulin secretion by high glucose was unaltered in IA-2/IA-2 $\beta$ KO islets (Fig. 2A).

\section{Effect of various stimuli}

Acetylcholine, arginine, and $\mathrm{KCl}$ rapidly and reversibly increased insulin secretion from control islets perifused with $8 \mathrm{mM}$ glucose (Fig. 3A). They also increased $\left[\mathrm{Ca}^{2+}\right]_{\mathrm{c}}$ (Fig. 3B). An obvious dissociation between the amplitude of the changes in $\left[\mathrm{Ca}^{2+}\right]_{\mathrm{c}}$ and insulin secretion was observed for acetylcholine.

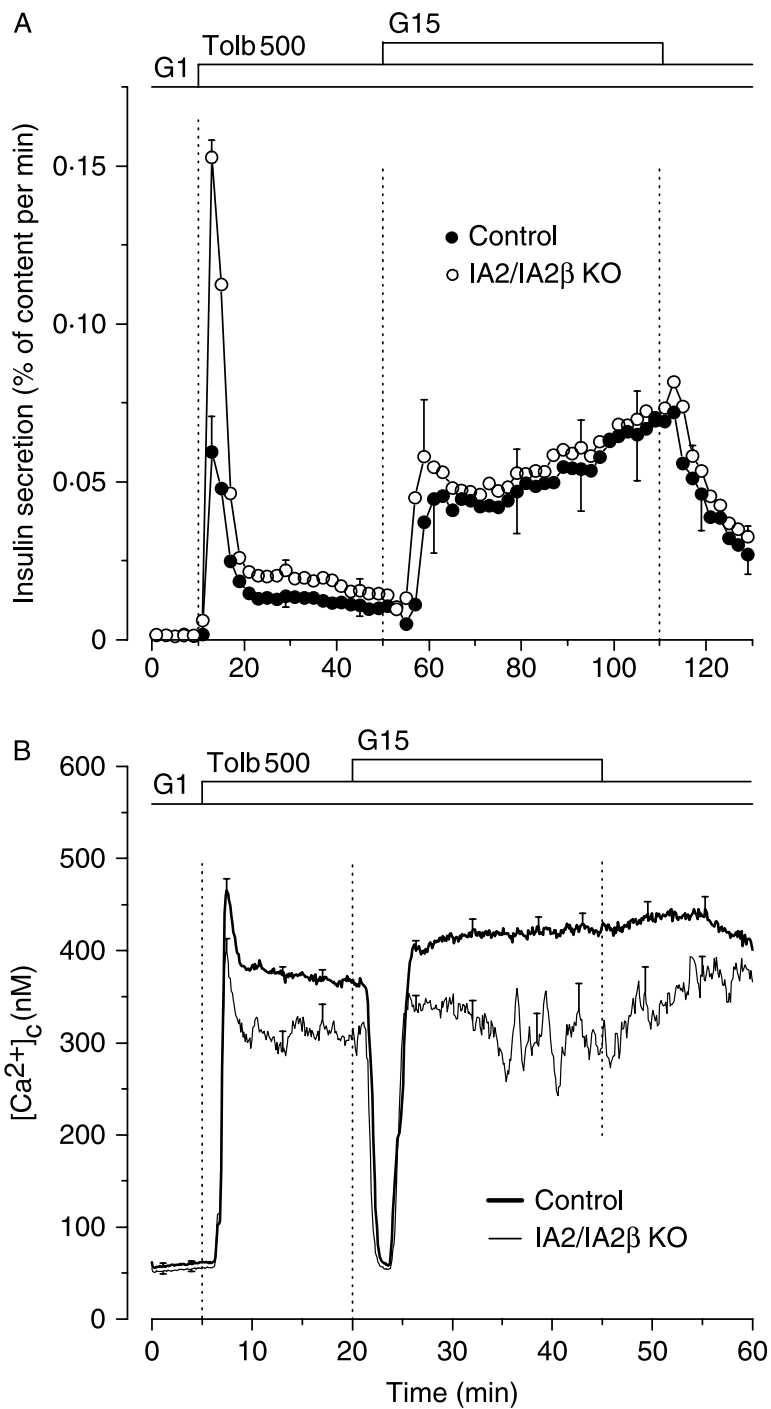

Figure 2 Influence of glucose on insulin secretion (A) and islet $\left[\mathrm{Ca}^{2+}\right]_{\mathrm{C}}(\mathrm{B})$ in the presence of a high concentration of tolbutamide. Control and IA-2/IA-2 $\beta$ KO islets were initially stimulated by $500 \mu \mathrm{M}$ tolbutamide (Tolb 500) in the presence of $1 \mathrm{mM}$ glucose (G1). The concentration of glucose was then increased to $15 \mathrm{mM}$ (G15) as indicated. Insulin secretion is expressed as a percentage of the islet insulin content, which averaged $155 \pm 10 \mathrm{ng}$ /islet for controls and $77 \pm 7 \mathrm{ng}$ /islet for tests. Values are means \pm S.E.M. for five experiments of insulin secretion and 21 islets from four mice for $\left[\mathrm{Ca}^{2+}\right]_{\mathrm{C}}$.

It can be explained by the activation of protein kinase $\mathrm{C}$ that augments secretion by an action distal to the rise in $\left[\mathrm{Ca}^{2+}\right]_{\mathrm{c}}$ (see Gilon \& Henquin 2001 for a review). The increases in $\left[\mathrm{Ca}^{2+}\right]_{c}$ induced by acetylcholine or $\mathrm{KCl}$ were similar $(P=0 \cdot 10)$ in IA-2/IA- $2 \beta \mathrm{KO}$ and control islets, and so were the fractional secretory responses (the absolute secretory responses were decreased). In contrast, arginine-induced insulin secretion was unaltered in absolute terms, so that the fractional secretory response to the amino acid was twice larger $(P<0 \cdot 01)$ in IA-2/ IA- $2 \beta \mathrm{KO}$ than control islets, while the increase in $\left[\mathrm{Ca}^{2+}\right]_{\mathrm{c}}$ only 


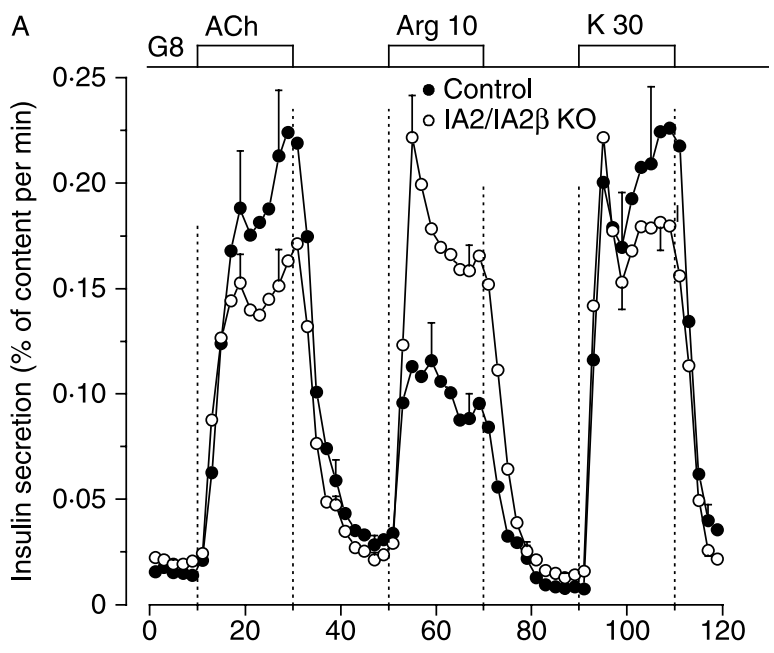

secretagogues (Ishiyama et al. 2006). Arginine was more potent on fractional insulin secretion in IA-2/IA- $2 \beta \mathrm{KO}$ islets than controls, at least in the presence of $5 \mathrm{mM}$ glucose alone $(P<0 \cdot 05)$ or with tolbutamide $(P<0 \cdot 01)$. Under these conditions, arginine caused a slightly larger increase in $\left[\mathrm{Ca}^{2+}\right]_{\mathrm{c}}(P<0 \cdot 01$; Fig. 4B).

We next compared the effects of leucine, which mainly acts through changes in $\beta$-cell metabolism (Newsholme et al. 2006),
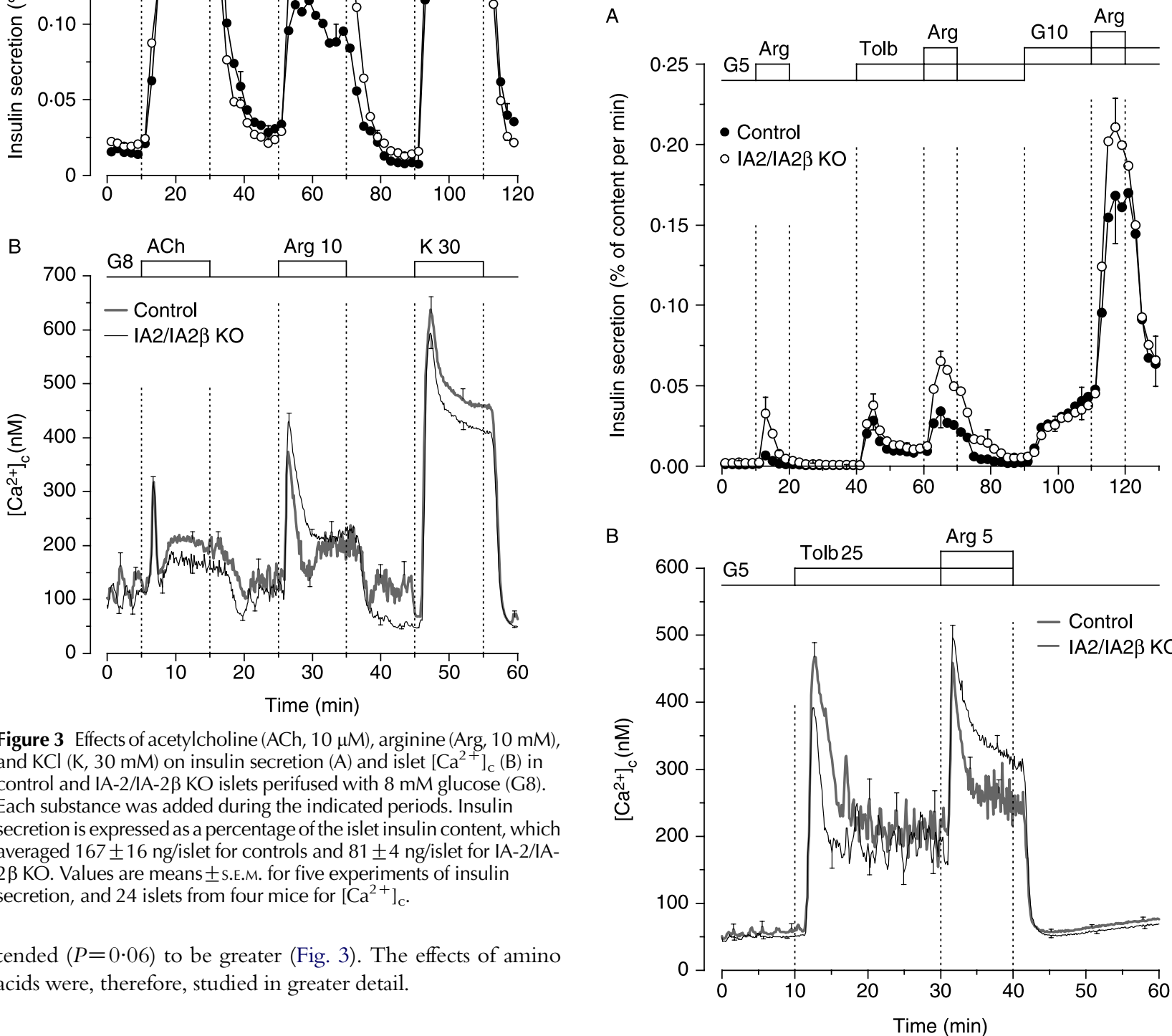

\section{Effects of amino acids}

In control islets, $5 \mathrm{mM}$ arginine had a negligible effect on insulin secretion in $5 \mathrm{mM}$ glucose, tripled the secretory rate in the presence of the mildly stimulatory concentration of $25 \mu \mathrm{M}$ tolbutamide, and was very potent in the combined presence of $10 \mathrm{mM}$ glucose and tolbutamide. This corresponds to the potentiation of arginine-induced insulin secretion by nonmetabolized (sulfonylurea) and metabolized (glucose)

Figure 4 Effects of arginine (Arg, $5 \mathrm{mM}$ ) on insulin secretion $(\mathrm{A})$ and islet $\left[\mathrm{Ca}^{2+}\right]_{\mathrm{C}}(\mathrm{B})$ in control and IA-2/IA-2 $\beta \mathrm{KO}$ islets. (A) Arginine was applied for 10-min pulses were applied in the presence of $5 \mathrm{mM}$ glucose (G5), $5 \mathrm{mM}$ glucose $+25 \mu \mathrm{M}$ tolbutamide (Tolb), and $10 \mathrm{mM}$ glucose (G10) + tolbutamide. (B) Tolbutamide and arginine were sequentially added to a medium containing $5 \mathrm{mM}$ glucose. Insulin secretion is expressed as a percentage of the islet insulin content, which averaged $168 \pm 10 \mathrm{ng} /$ islet in controls and $98 \pm 10 \mathrm{ng}$ in IA-2/IA-2 $\beta \mathrm{KO}$. Values are means \pm S.E.M. for five experiments of insulin secretion, and 23 islets from four mice for $\left[\mathrm{Ca}^{2+}\right]_{\mathrm{C}}$. 
alanine, whose effect is largely due to depolarization by cotransport with $\mathrm{Na}^{+}$(Newsholme et al. 2006), and lysine, a cationic amino acid thought to produce the same effects as arginine because of its transport in a charged form (Charles et al. 1982). Alanine was much less potent than the other two amino acids in inducing insulin secretion in control islets. All three induced a similar absolute response (not shown) corresponding to a greater $(P<0.05$ or less $)$ fractional secretory response in IA-2/IA- $2 \beta \mathrm{KO}$ islets, although the difference with controls developed only late during alanine application (Fig. 5A).
These differences were not attributable to differences in the $\left[\mathrm{Ca}^{2+}\right]_{\mathrm{c}}$ increase produced by the amino acids $(P=0 \cdot 05$ for lysine; Fig. 5B).

In a last series of experiments, the order of stimulation was changed: lysine was applied first, followed by alanine, and then by leucine (Fig. 6). The results were qualitatively similar for lysine and alanine, which caused similar $\left[\mathrm{Ca}^{2+}\right]_{\mathrm{c}}$ changes but larger fractional insulin responses $(P<0 \cdot 005)$ in IA-2/IA-2 $\beta$ KO than control islets. However, leucine-induced insulin secretion was no longer larger in IA-2/IA- $2 \beta \mathrm{KO}$ than control islets.
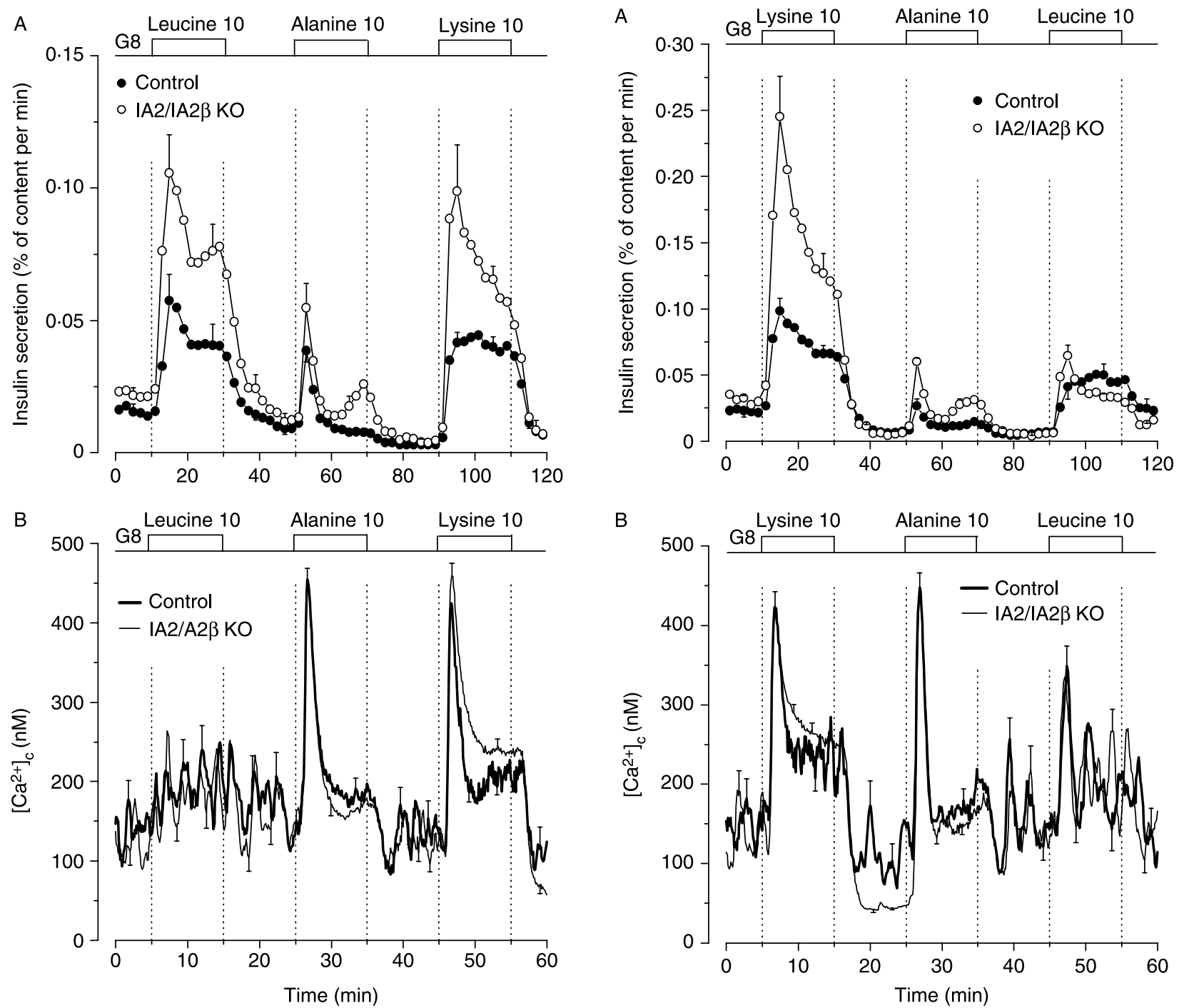

Figure 5 Effects of amino acids on insulin secretion $(A)$ and islet $\left[\mathrm{Ca}^{2+}\right]_{\mathrm{C}}(\mathrm{B})$ in control and IA-2/IA-2 $\beta \mathrm{KO}$ islets. Leucine, alanine, and lysine (each at $10 \mathrm{mM}$ ) were added to a medium containing $8 \mathrm{mM}$ glucose (G8) as indicated. Insulin secretion is expressed as a percentage of the islet insulin content, which averaged 165 \pm $15 \mathrm{ng}$ /islet in controls and $93 \pm 16 \mathrm{ng}$ /islet in IA-2/IA-2 $\beta$ KO. Values are means \pm S.E.M. for five experiments of insulin secretion and 24 islets from four mice for $\left[\mathrm{Ca}^{2+}\right]_{\mathrm{c}}$.

Figure 6 Effects of amino acids on insulin secretion $(A)$ and islet $\left[\mathrm{Ca}^{2+}\right]_{\mathrm{C}}(\mathrm{B})$ in control and IA-2/IA-2 $\beta \mathrm{KO}$ islets. Lysine, alanine, and leucine (each at $10 \mathrm{mM}$ ) were added to a medium containing $8 \mathrm{mM}$ glucose (G8) as indicated. Insulin secretion is expressed as a percentage of the islet insulin content, which averaged 146 \pm $11 \mathrm{ng} /$ islet in controls and $88 \pm 16 \mathrm{ng}$ /islet in IA2-IA2 $\beta$ KO. Values are means \pm S.E.M. for five experiments of insulin secretion and 23 islets from four mice for $\left[\mathrm{Ca}^{2+}\right]_{\mathrm{C}}$. 


\section{Discussion}

Our study shows that insulin secretory changes induced by glucose and other modulators of $\beta$-cell function are qualitatively normal in mouse islets lacking both IA-2 and IA-2 $\beta$. However, quantitative differences exist, which could at least partly be accounted for by the differences in insulin stores. Thus, the insulin content of IA-2/IA- $2 \beta$ KO islets was $\sim 50 \%$ lower than that in controls and the absolute secretory rate was often reduced in a similar proportion.

When differences in insulin secretion are measured between control and test preparations that contain similar amounts of insulin, it is straightforward to conclude that some step of stimulus-secretion coupling is affected by the treatment. On the other hand, when the insulin content of the two preparations is different, it may be problematic to ascribe the observed differences in secretion to these differences in content, to alterations in stimulus-secretion coupling or both. One should certainly not assume that a decrease in insulin stores by half (as here in IA-2/IA-2 $\beta \mathrm{KO}$ islets) is unlikely to limit an acute secretory response because the latter does not exceed $2-3 \%$ of the insulin content over $1 \mathrm{~h}$. Insulin granules are indeed distributed in functionally distinct pools of markedly different sizes (Rorsman \& Renström 2003). It is, therefore, common practice to compare the insulin contents of the preparations and, when these are unequal, to express the secretion rate relative to this content (Peyot et al. 2004, Nolan et al. 2006, Saleh et al. 2006, Wang et al. 2007). When the secretory response to various stimuli is consistently increased or decreased in proportion of the change in insulin content, the direct influence of the latter is highly plausible. In the present study, however, the absolute rate of insulin secretion (on an islet basis) was occasionally unchanged versus controls (first-phase response to glucose or tolbutamide, response to amino acids) and often decreased in proportion to insulin stores. We are not aware of other models showing such a complex behavior. The changes in insulin secretion observed in IA-2/IA- $2 \beta \mathrm{KO}$ islets may thus be multifactorial, influenced by both alterations in the releasing process and changes in insulin granule availability. We therefore chose to express the results as a fractional secretion rate. Nevertheless, this calculation of the fractional secretory rate for the interpretation of in vitro data should not obscure the fact that what matters in vivo is the absolute amount of insulin delivered in the blood.

Previous studies using incubated islets, a technique that essentially measures second phase of insulin secretion, have reported that the secretory response to high glucose is decreased by $35-45 \%$ in IA- $2 \beta \mathrm{KO}$ and IA- $2 \mathrm{KO}$ islets respectively when compared with control islets (Saeki et al. 2002, Kubosaki et al. 2004). Our experiments, using a dynamic system of perifusion, show that this inhibition is restricted to the second phase, with no impairment of first phase. They further establish that the knockout of both IA- 2 and IA- $2 \beta$ does not cause a much greater inhibition than any single knockout, and attribute many of the differences in insulin secretion to that in insulin content of the islets. Our findings of lower amounts of insulin in test than control islets are compatible with the observations made in the insulin-secreting MIN6 cell line. Thus, knockdown of IA-2 with siRNA decreased the insulin content, whereas overexpression of IA-2 increased it (Harashima et al. 2005). These findings are also consistent with electron microscopic studies showing a $\sim 50 \%$ decrease in the number of DCV per $\beta$-cell in IA-2/IA-2 $\beta \mathrm{KO}$ islets when compared with control islets (Cai et al. manuscript in preparation). All these observations are in keeping with the proposal that the presence and processing of IA2 during exocytosis of insulin granules might provide a positive signal to maintain insulin stores (Trajkovski et al. 2004). Whether the loss of IA-2 and IA-2 $\beta$ has independent or interrelated impacts on proinsulin biosynthesis and insulin granule biogenesis or turnover certainly warrants further specific studies.

Insulin secretion is triggered by an increase in $\left[\mathrm{Ca}^{2+}\right]_{\mathrm{c}}$ in $\beta$-cells (Henquin et al. 2003). The increase in $\left[\mathrm{Ca}^{2+}\right]_{c}$ produced by glucose, tolbutamide, or $\mathrm{KCl}$ was slightly (or tended to be) smaller in IA-2/IA-2 $\beta$ KO than control islets. This decrease could contribute to the lowering of absolute insulin secretion rate during second phase but, in our view, is too small to explain it completely, inasmuch as absolute first phases were not depressed. It is striking that fractional insulin secretion was similar during steady state and was even higher during first-phase responses to glucose or tolbutamide. Moreover, two cationic amino acids, arginine and lysine, produced a similar (or marginally larger) increase in $\left[\mathrm{Ca}^{2+}\right]_{c}$ in IA-2/IA-2 $\beta \mathrm{KO}$ than control islets, but induced twice larger fractional secretory responses. These observations not only show that neither IA-2 nor IA- $2 \beta$ is indispensable for exocytosis of insulin granules, but also further suggest that their absence facilitates the secretory response to the triggering $\mathrm{Ca}^{2+}$ signal, perhaps by suppressing the interaction with proteins (Ort et al. 2001, Hu et al. 2005) that impede rather than promote granule access to the exocytotic sites. Insulin secretion also can be augmented by metabolic and neurohormonal amplifying pathways via mechanisms that do not involve a further rise in $\left[\mathrm{Ca}^{2+}\right]_{\mathrm{c}}$ but an increase in $\mathrm{Ca}^{2+}$ efficacy (Henquin et al. 2003). Since the amplification of insulin secretion by glucose itself, by protein kinase A (forskolin), or by protein kinase C (acetylcholine) was virtually identical in test and control islets when the difference in insulin stores was taken into account, our results argue that neither pathway is altered by the lack of IA- 2 and IA- $2 \beta$.

Compared with wild-type mice, IA-2/IA-2 $\beta$ KO mice showed glucose intolerance after ip glucose injection. Their plasma insulin levels barely changed and the prominent early increase observed in controls was strikingly missing (Kubosaki et al. 2005). In contrast, our present in vitro studies show that high glucose evoked a biphasic secretion of insulin with a first phase that was not smaller than that in control islets despite the lower insulin stores (Fig. 1). Since the difference between in vivo and in vitro findings cannot be attributed to a weaker in vivo stimulus (plasma glucose increased to more than $15 \mathrm{mM}$ ), it is likely that factors extrinsic to the islets are involved. On the other hand, the smaller absolute secretion of insulin during second phase 
probably accounts for the impaired elevation of plasma insulin levels at later time points of the imposed hyperglycemia.

An intriguing feature of the in vivo studies was that, unlike glucose, arginine produced a rapid increase in plasma insulin levels in IA-2/IA-2 $\beta$ KO mice (Kubosaki et al. 2005). This is fully compatible with the present in vitro observations that arginine-induced insulin secretion was not depressed in spite of the reduction in insulin stores (hence the higher fractional insulin secretion rate). This preserved responsiveness of IA-2/ IA- $2 \beta \mathrm{KO}$ islets to stimulation by arginine was not specific to this amino acid. It was also observed with lysine, another cationic amino acid, alanine, and leucine at least when it was tested as the first stimulus. Since the three amino acids affect $\beta$-cell function by different mechanisms (Newsholme et al. 2006), we have no mechanistic explanation for this higher responsiveness of IA-2/IA-2 $\beta \mathrm{KO}$ islets to amino acids.

In conclusion, IA-2 and IA- $2 \beta$ proteins, two major islet autoantigens in type 1 diabetes, are not critical for acute stimulus-secretion coupling in $\beta$-cells. Their knockout even facilitates insulin secretion via both triggering and amplifying pathways. In fact, IA-2 and IA- $2 \beta$ may be more important for optimal replenishment of insulin stores, the decrease of which probably explains much of the perturbation of glucose homeostasis in IA-2/IA-2 $\beta$ KO mice. Since both proteins are located in DCV of many endocrine and neuroendocrine cells, their role is likely to extend beyond the pancreatic $\beta$-cell. The recently reported decrease in storage and secretion of luteinizing hormone in the infertile IA-2/IA-2 $\beta \mathrm{KO}$ female mice is an example of such a role (Kubosaki et al. 2006).

\section{Acknowledgements}

We thank F Knockaert for technical assistance. This work was supported in part by the Fonds de la Recherche Scientifique Medicale (3.4552.04 and 3.4530.08), the Belgian Science Policy (PAI 6/40), and the Direction de la Recherche Scientifique of the French Community of Belgium (ARC 05/10-328). The authors have no conflict of interest to declare.

\section{References}

Ammala C, Ashcroft FM \& Rorsman P 1993 Calcium-independent potentiation of insulin release by cyclic AMP in single $\beta$-cells. Nature 363 356-358.

Charles S, Tamagawa T \& Henquin JC 1982 A single mechanism for the stimulation of insulin release and ${ }^{86} \mathrm{Rb}$ efflux from rat islets by cationic amino acids. Biochemical Journal 208 301-308.

Cui L, Yu WP, DeAizpurua HJ, Schmidli RS \& Pallen CJ 1996 Cloning and characterization of islet cell antigen-related protein-tyrosine phosphatase (PTP), a novel receptor-like PTP and autoantigen in insulin-dependent diabetes. Journal of Biological Chemistry $27124817-24823$.

Doi A, Shono T, Nishi M, Furuta H, Sasaki H \& Nanjo K 2006 IA-2 $\beta$, but not IA-2, is induced by ghrelin and inhibits glucose-stimulated insulin secretion. PNAS 103 885-890.
Gilon P \& Henquin JC 1992 Influence of membrane potential changes on cytoplasmic $\mathrm{Ca}^{2+}$ concentration in an electrically excitable cell, the insulin-secreting pancreatic $\beta$-cell. Journal of Biological Chemistry 267 20713-20720

Gilon P \& Henquin JC 2001 Mechanisms and physiological significance of the cholinergic control of the pancreatic $\beta$-cell function. Endocrine Reviews 22 565-604.

Harashima SI, Clark A, Christie MR \& Notkins AL 2005 The dense core transmembrane vesicle protein IA-2 is a regulator of vesicle number and insulin secretion. PNAS 102 8704-8709.

Heding LG 1972 Determination of total serum insulin (IRI) in insulin-treated diabetic patients. Diabetologia 8 260-266.

Henquin JC, Ravier MA, Nenquin M, Jonas JC \& Gilon P 2003 Hierarchy of the $\beta$-cell signals controlling insulin secretion. European Journal of Clinical Investigation 33 742-750.

Henquin JC, Nenquin M, Stiernet P \& Ahren B 2006 In vivo and in vitro glucose-induced biphasic insulin secretion in the mouse: pattern and role of cytoplasmic $\mathrm{Ca}^{2+}$ and amplification signals in $\beta$-cells. Diabetes 55 441-451.

Hu YF, Zhang HL, Cai T, Harashima S \& Notkins AL 2005 The IA-2 interactome. Diabetologia 48 2576-2581.

Ishiyama N, Ravier MA \& Henquin JC 2006 Dual mechanism of the potentiation by glucose of insulin secretion induced by arginine and tolbutamide. American Journal of Physiology 290 E540-E549.

Jonas JC, Gilon P \& Henquin JC 1998 Temporal and quantitative correlations between insulin secretion and stably elevated or oscillatory cytoplasmic $\mathrm{Ca}^{2+}$ in mouse pancreatic $\beta$ cells. Diabetes 47 1266-1273.

Kawasaki E, Hutton JC \& Eisenbarth GS 1996 Molecular cloning and characterization of the human transmembrane protein tyrosine phosphatase homologue, phogrin, an autoantigen of type 1 diabetes. Biochemical and Biophysical Research Communications 227 440-447.

Kubosaki A, Gross S, Miura J, Saeki K, Zhu M, Nakamura S, Hendricks W \& Notkins AL 2004 Targeted disruption of the IA-2 $\beta$ gene causes glucose intolerance and impairs insulin secretion but does not prevent the development of diabetes in NOD mice. Diabetes 53 1684-1691.

Kubosaki A, Nakamura S \& Notkins AL 2005 Dense core vesicle proteins IA2 and IA-2 $\beta$. Metabolic alterations in double knockout mice. Diabetes $\mathbf{5 4}$ S46-S51.

Kubosaki A, Nakamura S, Clark A, Morris JF \& Notkins AL 2006 Disruption of the transmembrane dense core vesicle proteins IA-2 and IA-2 $\beta$ causes female infertility. Endocrinology 147 811-815.

Lan MS, Lu J, Goto Y \& Notkins AL 1994 Molecular cloning and identification of a receptor-type protein tyrosine phosphatase, IA-2, from human insulinoma. DNA and Cell Biology 13 505-514.

Löbner K, Steinbrenner H, Roberts GA, Ling Z, Huang GC, Piquer S, Pipeleers DG, Seissler J \& Christie MR 2002 Different regulated expression of the tyrosine phosphatase-like proteins IA-2 and phogrin by glucose and insulin in pancreatic islets. Relationship to development of insulin secretory responses in early life. Diabetes $\mathbf{5 1}$ 2982-2988.

Lu J, Li Q, Xie H, Chen ZJ, Borovitskaya AE, Maclaren NK, Notkins AL \& Lan MS 1996 Identification of a second transmembrane protein tyrosine phosphatase, IA-2 $\beta$, as an autoantigen in insulin-dependent diabetes mellitus: precursor of the 37-kDa tryptic fragment. PNAS 93 2307-2311.

Mziaut H, Trajkovski M, Kersting S, Ehninger A, Altkrüger A, Lemaitre RP, Schmidt D, Saeger HD, Lee MS, Drechsel DN et al. 2006 Synergy of glucose and growth hormone signaling in islet cells through ICA512 and STAT5. Nature Cell Biology 8 435-445.

Newsholme P, Brennan L \& Bender K 2006 Amino acid metabolism, $\beta$-cell function, and diabetes. Diabetes 55 S39-S47.

Nolan CJ, Leahy JL, Delghingaro-Augusto V, Moibi J, Soni K, Peyot ML, Fortier M, Guay C, Lamontagne J, Barbeau A et al. 2006 Beta cell compensation for insulin resistance in Zucker fatty rats: increased lipolysis and fatty acid signaling. Diabetologia 49 2120-2130.

Notkins AL \& Lernmark A 2001 Autoimmune type 1 diabetes: resolved and unresolved issues. Journal of Clinical Investigation 108 1247-1252.

Ort T, Voronov S, Guo J, Zawalich K, Froehner SC, Zawalich W \& Solimena M 2001 Dephosphorylation of $\beta 2$-syntrophin and $\mathrm{Ca}^{2+} / \mu$-calpainmediated cleavage of ICA512 upon stimulation of insulin secretion. EMBO Journal 20 4013-4023. 
Panten U, Christians J, Kriegstein EV, Poser W \& Hasselblatt A 1973 Effect of carbohydrates upon fluorescence of reduced pyridine nucleotides from perifused isolated pancreatic islets. Diabetologia 9 477-482.

Peyot ML, Nolan CJ, Soni K, Joly E, Lussier R, Corkey BE, Wang SP, Mitchell GA \& Prentki M 2004 Hormone-sensitive lipase has a role in lipid signaling for insulin secretion but is nonessential for the incretin action of glucagon-like peptide 1. Diabetes 53 1733-1742.

Rabin DU, Pleasic SM, Shapiro JA, Yoo-Warren H, Oles J, Hicks JM, Glodstein DE \& Rae PMM 1994 Islet antigen 512 is a diabetes-specific islet autoantigen related to protein tyrosine phosphatases. Journal of Immunology 152 3183-3188.

Rorsman P \& Renström E 2003 Insulin granule dynamics in pancreatic beta cells. Diabetologia 46 1029-1045.

Saeki K, Zhu M, Kubosaki A, Xie J, Lan MS \& Notkins AL 2002 Targeted disruption of the protein tyrosine phosphatase-like molecule IA-2 results in alterations in glucose tolerance tests and insulin secretion. Diabetes $\mathbf{5 1}$ 1842-1850.

Saleh MC, Wheeler MB \& Chan CB 2006 Endogenous islet uncoupling protein-2 expression and loss of glucose homeostasis in $o b / o b$ mice. Journal of Endocrinology 190 659-667.

Sato Y, Anello M \& Henquin JC 1999 Glucose regulation of insulin secretion independent of the opening or closure of adenosine triphosphate-sensitive $\mathrm{K}^{+}$channels in $\beta$ cells. Endocrinology 140 2252-2257.

Seissler J, Nguyen TBT, Aust G, Steinbrenner H \& Scherbaum WA 2000 Regulation of the diabetes-associated autoantigen IA-2 in INS-1 pancreatic $\beta$-cells. Diabetes 49 1137-1141.

Solimena M, Dirkx R Jr, Hermel JM, Pleasic-Williams S, Shapiro JA, Caron L \& Rabin DU 1996 ICA512, an autoantigen of type I diabetes, is an intrinsic membrane protein of neurosecretory granules. EMBO Journal $\mathbf{1 5}$ 2102-2114.
Tamagawa T, Niki H \& Niki A 1985 Insulin release independent of a rise in cytosolic free $\mathrm{Ca}^{2+}$ by forskolin and phorbol ester. FEBS Letters 183 430-432.

Trajkovski M, Mziaut H, Altkrüger A, Ouwendijk J, Knoch KP, Müller S \& Solimena M 2004 Nuclear translocation of an ICA512 cytosolic fragment couples granule exocytosis and insulin expression in $\beta$-cells. Journal of Cell Biology 167 1063-1074.

Vo YP, Hutton JC \& Angleson JK 2004 Recycling of the dense-core vesicle membrane protein phogrin in Min6 $\beta$-cells. Biochemical and Biophysical Research Communications 324 1004-1010.

Wang H, Brun T, Kataoka K, Sharma AJ \& Wollheim CB 2007 MAFA, controls genes implicated in insulin biosynthesis and secretion. Diabetologia $50348-358$

Wasmeier C \& Hutton JC 1996 Molecular cloning of phogrin, a proteintyrosine phosphatase homologue localized to insulin secretory granule membranes. Journal of Biological Chemistry 271 18161-18170.

Wasmeier C \& Hutton JC 1999 Secretagogue-dependent phosphorylation of phogrin, an insulin granule membrane protein tyrosine phosphatase homologue. Biochemical Journal 341 563-569.

Wasmeier C \& Hutton JC 2001 Secretagogue-dependent phosphorylation of the insulin granule membrane protein phogrin is mediated by cAMP-dependent protein kinase. Journal of Biological Chemistry 276 31919-31928.

Received in final form 29 November 2007

Accepted 10 December 2007

Made available online as an Accepted Preprint 10 December 2007 